\title{
Nenoteiksme, modalitāte un verba nullformas latviešu valodā
}

\section{Infinitive, modality and zero forms of verb in Latvian}

\author{
Andra Kalnača \\ Latvijas Universitāte, Humanitāro zinātņu fakultāte \\ Latviešu un vispārīgās valodniecības katedra \\ Visvalža iela 4a, Rīga LV-1050 \\ E-pasts: kalnaca@latnet.lv
}

\begin{abstract}
Nenoteiksme vienkārša verbāla izteicēja funkcijā blakus verba izteiksmēm un dažādām modālām konstrukcijām ar nenoteiksmi (saliktiem verbāliem izteicējiem, ko veido modāli verbi kopā ar nenoteiksmi, kā arī verbāliem sastata izteicējiem bija/būs + nenoteiksme) ir viens no modalitātes izteikšanas veidiem latviešu valodā. Nenoteiksme predikatīvā funkcijā un arī citas modālas konstrukcijas parasti izsaka vai nu deontisku, vai arī epistēmisku modalitāti. Pētījumā tiek risināts jautājums par attieksmēm starp nenoteiksmi un modālām konstrukcijām ar nenoteiksmi, kā arī to izteikto modalitāti.

Pētījuma gaitā analizēts, kāpēc latviešu valodā nevar uzskatīt, ka nenoteiksme izteicējā īstenojas tikai kopā ar reālu vai potenciālu modālu verbu, proti, kāpēc nevar runāt par modāla verba (vai citas nozīmes verba) nullformu. Nenoteiksme kā vienkāršs verbāls izteicējs latviešu valodā pārstāv lai gan marginālu, bet tomēr īpašu sintaktisku konstrukciju. Pētījuma gaitā secināts, ka blakus nenoteiksmei nav postulējama ne modāla verba, ne ir nullforma.
\end{abstract}

Atslēgvārdi: nenoteiksme, modalitāte, izteiksme, nullforma, noliegums, elipse.

\section{levads}

Raksts tapis kā pārdomas par modalitātes izteikšanas līdzekḷiem un to hierarhiju latviešu valodā, turpinot autores jau iepriekšējās publikācijās ietvertās idejas (sk., piem., Kalnača 2013a; 2013b; 2014).

Lasot Aldonas Paulauskienes (Aldona Paulauskiene 2014) recenziju par autoru kolektīva publicēto „Latviešu valodas gramatiku” (Dainas Nītinas un Jura Grigorjeva redakcijā 2013), uzmanību saista recenzentes piezīme nenoteiksmes funkciju apskatā, $\mathrm{ka}$, ,.. bendratis tariniu gali eiti tik su modaliniais veiksmažodžiais, realiais ir potenciniais." [.. nenoteiksme teikumā var būt kopā tikai ar modālu verbu, reālu vai potenciālu - raksta autores tulkojums] (Paulauskienė 2014, 383). Šeit, norādot, ka nenoteiksme viena pati nevar būt izteicējs un ka blakus nenoteiksmei iespējama modāla verba nullforma, iezīmējas visai krasa nenoteiksmes predikatīvo funkciju izpratnes atšksirība no latviešu valodniecībā tradicionālā uzskata. Lietuviešu valodniecībā parasti, aprakstot nenoteiksmes funkcijas, tiek norādīts, ka, lietota izteicējā, nenoteiksme visbiežāk ir saistīta ar kāda modāla verba vai, 
retāk, verba $\boldsymbol{b} \bar{u} \boldsymbol{t}$ nullformu, t. i., nenoteiksme tiek interpretēta vai nu kā salikts verbāls izteicējs, vai arī kā verbāls sastata izteicējs (sk., piem., Paulauskienẻ 1994; Ambrazas 1996).

Turpretī latviešu valodniecībā pašsaprotams ir viedoklis, ka nenoteiksme teikumā var veidot īpašu izteicēja tipu - vienkāršu verbālu izteicēju (sk., piem., Lokmane 2013, 718). Savukārt modāls vai fāzes verbs kopā ar nenoteiksmi ir salikts verbāls izteicējs (sk., piem., Lokmane op. cit.), par modāla (fāzes) verba nullformām latviešu gramatikā vispār netiek runāts (sk., piem., Ivulāne 2015 par palīgnozīmē lietotu verbu sistēmu un funkcijām latviešu valodā). Tādējādi uzmanības vērts un rakstā plašāk aplūkots ir jautājums par nenoteiksmes, modalitātes un verba nullformas interpretāciju latviešu valodā - kādas ir šo jēdzienu un ar tiem saistīto valodas vienību savstarpējās attieksmes.

\section{Modalitātes izteikšanas līdzekḷi latviešu valodā}

Lai skaidrāk izprastu latviešu un lietuviešu gramatikas atšķirīgās interpretācijas cēloṇus nenoteiksmes un tās funkciju aprakstā, vispirms svarīgi vēlreiz pārskatīt gramatiskos modalitātes izteikšanas līdzekḷus latviešu valodā. Tie ir (Kalnača 2013a):

1) verba izteiksmes (īstenības (1a), pavēles (1b), atstāstījuma (1c), vēlējuma (1d) un vajadzības (1e) izteiksme):

(1) a. Tā nu jūtu, ka laikam būšs apaukstējies. (www.delfi.lv)

b. Pazüdiet no šejienes! (J. Joņevs)

c. - Varbūt nemaz nav tādas koncertu vietas?

- It kā laikam noteikti esot. (J. Joņevs)

d. Ja varētu aprakstīt ūdens mirdzēšanu, varētu aprakstìt visu. (N. Ikstena)

e. Ierēdnim augstais amats ministrijā būs jāatstājj. (www.delfi.lv)

2) modālas konstrukcijas:

a) modāls verbs ${ }^{1}$ (t. s. modificètājss) + nenoteiksme:

$a_{1}$ ) subjekts nominatīvā

(2) Man nav tādas sajūtas, ka es varu atpūsties. (www.lsm.lv)

$\mathrm{b}_{1}$ ) subjekts datīvā

(3) Šo [mūzikas] albūmu nevajag klausīties cilvēkiem ar depresīvām nosliecēm. (J. Jon,evs)

1 Šai rakstā tiek lietots termins modāls verbs, atsakoties no latviešu valodniecībā tradicionāli izmantotā, taču terminoloğiski neskaidrā apzīmējuma modificètājs. Ar modificētāju (modifier) sintaksē parasti saprot strukturāli atkarīgu vārdu, teikuma daļu vai teikumu (sk., piem., Matthews 1997, 229; Crystal 1997, 245-246) neatkarīgi no modalitātes. Termins modāls verbs visplašākajā nozīmē 'verbs, kas izsaka (deontisku vai epistēmisku) modalitāti' (sal. Matthews 1997, 228) precīzāk atbilst semantiskai latviešu valodas darbības vārdu grupai, kas izsaka dažādas modālas nozīmes (gribēt, varēt, spēt, vajadzēt, vēlèties, nākties u. c.). 
b) $\quad$ bija/būs + nenoteiksme

(4) Tev nebūs par mani visu zināt! (www.apollo.lv)

c) $\quad \mathrm{ir} / \mathrm{bija} / \mathrm{bu} s+$ tagadnes pasīvais divdabis

(5) Balkona durvis nebija atveramas. (J. Joņevs)

3) nenoteiksme:

(6) a. Viņš ir pilsētas mēers, un šai amatā viņam palikt. (Diena)

b. Kaut ātrāk tikt atvaļinājumāa! (www.apollo.lv)

Visi minētie līdzekḷi izsaka vai nu deontisku ((1b), (1e), (3), (4), (6a) piemēri), vai arī epistēmisku modalitāti ((1a), (1c), (1d), (2), (5), (6b) piemēri) (plašāk sk. Kalnača 2013b).

Nenoteiksmes modāls lietojums neatkarīgi no izteicēja tipa sintaktiski var 1̄stenoties gan saistījumā ar netiešo teikuma priekšmetu datīvā ((6a) piemērs), gan bez tā ((6b) piemērs).

Tātad galvenais pētījumā risināmais jautājums ir morfosintaktiskas dabas kādas ir attieksmes starp nenoteiksmi un modālām konstrukcijām ar nenoteiksmi, kā arī to izteikto modalitāti. Rakstā nav iecerēts aplūkot, vai nenoteiksme izteicēja funkcijā ir īpašs izteicēja tips (resp., vienkāršs verbāls izteicējs) vai arī tā pārstāv saliktu verbālu izteicēju ar modāla verba nullformu (par to tuvāk sk. Ilzes Lokmanes (2016) rakstu šai krājumā):

(7) Ko man ø (vajag? gribas?) darīt?

Kā jau minēts raksta ievadā, latviešu un lietuviešu valodniecībā šie jautājumi tradicionāli aprakstīti pretēji.

\section{Artura Ozola analītiskā debitīva koncepcija}

Lai saprastu latviešu valodniecības tradīcijas cēloņus, svarīgi ir atcerēties Artura Ozola (1912-1964) postulēto latviešu valodas analītisko debitīvu (Ko man darīt?; Ko man bija darīt?; Ko man būs darīt?) un šīs konstrukcijas aprakstu. Artura Ozola interpretācijā analītiskais debitīvs ir sintētiskā debitīva, t. i., vajadzības izteiksmes analogs, jo abas formas bieži ir savstarpēji aizstājamas (Ozols 1993, 90-98). Tāpat kā sintētiskajam debitīvam ir tagadnes, pagātnes un nākotnes forma (man jāraksta, man bija jāraksta, man būs jāraksta), arī analītiskajam debitīvam ir tāda pati laika formu paradigma (man darìt, man bija darīt, man būs darīt). Tātad A. Ozola uzskatā analītisko debitīvu veido šāda sintaktiska konstrukcija ar trīs laika formu paradigmu - tagadni (8a), pagātni (8b), nākotni (8c):

(8) datīvs + o/bija/būs + nenoteiksme

a. Kā man izskaidrot jūsu laipnību? (I. Ābele)

b. Ko man bija iesākt ar saviem liekajiem 15 kilogramiem? (www.tvnet.lv)

c. Tiem cilvēkiem jau nu nebūs sēèet valsts svinīgajos pasākumos un kur nu vēl pieņemšanās. (Latvijas Avīze) 
Zīmīgi, ka A. Ozola analītiskā debitīva tagadnes formai tipiska ir palīgdarbības vārda ir nullforma - latviešu valodā nav atrodams neviens piemērs, kur būtu lietota konstrukcija datīvs + ir + nenoteiksme:

\section{(9) *Ko man tagad ir darīt?}

Tas liek domāt, ka A. Ozola analītiskais debitīvs pārstāv nevis vienotu paradigmu, bet gan divējādu darbības vārda formu modālu lietojumu verbālā izteicējā, kam abos gadījumos iespējams (bet ne obligāts) teikuma priekšmets datīvā (par to sk. arī Kalnača 2013a, 2013b; Lokmane 2014):

1) nenoteiksmi (sk. (8a) piemēru);

2) konstrukciju bija/būs + nenoteiksme (sk. (8b-c) piemērus).

Lai gan Artura Ozola analītiskā debitīva ideja latviešu gramatikā nav akceptēta un tālāk attīstīta (par iemesliem plašāk sk. Kalnača 2013a), tomēr tā izskaidro, kāpēc nenoteiksme un konstrukcijas bija/būs + nenoteiksme tradicionāli aprakstītas kā debitīva analogi - t. s. citi vajadzības izteikšanas lìdzeklıi (sk., piem., Ahero et al. 1959, 621-623; Paegle 2003, 119; Kalnača 2013b, 489-491).

Vajadzības un nepieciešamības izteikšanā latviešu valodā galvenā loma ir debitīvam. Konstrukcijas ar modāliem verbiem (piem., vajadzēt, nākties) un verbiem bija/būs, kā arī ar nenoteiksmi kā verbālu izteicēju, kas dạ̦ēji veido debitīva gramatisko sinonīmiju, attiecībā pret debitīvu lietojuma zin̄ā ir marginālas. Iespējams, tāpēc modalitātes un arī ar tās izteikšanu saistīto gramatisko formu un konstrukciju apraksts veidots no piecu izteiksmju un to ietverto gramatisko formu pozīcijas, kur būtiska loma ir tieši debitīvam, nevis modālajiem verbiem.

Nenoteiksmes un konstrukciju bija/būs + nenoteiksme semantisks paralēlums ar debitīvu arī ir būtisks iemesls, kāpēc jautājums par varbūtēju modāla verba nullformu blakus nenoteiksmei latviešu valodniecībā nekad nav izvirzīts, sal. (10a-b) un (10c) piemērus:

\section{(10) a. Ko man vajadzēja darīt? \\ b. Ko man vajadzēs darīt? \\ c. *Ko man o (vajag) darīt?}

Par to, ka nenoteiksme un konstrukcijas modāls verbs + nenoteiksme nav viena tipa parādības, liecina tas, ka latviešu valodā modāli verbi var būt saistīti gan ar subjektu nominatīvā (varēt, spēt, gribèt, sk. arī (2) piemēru), gan datīvā (vajadzēt, gribēties, laimēties, sk. arī (3) piemēru), turklāt šādi verbi modalitātes ziņā ir dažādi neatkarīgi no subjekta morfoloǵiskās formas.

Atšķirīiba ir arī tā, ka modāls verbu lietojums latviešu valodā nav ierobežots ne laika formu, ne izteiksmju ziṇā (sk. (11) piemērus), tāpat iespējami visi teikuma komunikatīvie tipi - apgalvojums (11a-b), jautājums (11c), rosinājums (11d):

(11) a. Es vienmēr esmu varējusi daudz strādāt.

b. Viņš bija gribējis nopirkt lielāku dzīvokli.

c. Man esot vajadzējis iet mājās?

d. Man vajadzêtu iet mājās! 
Turpretī nenoteiksme izteicējā vai konstrukcija bija/būs + nenoteiksme latviešu valodā ir ierobežota formu zin̄ā, jo parasti sastopama tikai īstenības izteiksmes vienkāršajās laika formās jautājuma vai izsaukuma, bet ne stāstījuma teikumos (sk., piem., šì raksta (4), (6b), (8) piemēru).

Tādējādi latviešu valodniecībā jau kopš A. Ozola (1993 [1961]) pētījumiem un ar̄̄ „Mūsdienu latviešu literārās valodas gramatikas” (Ahero et al. 1959) blakus verba izteiksmēm un tieši debitīvam tiek runāts par dažādām modālām konstrukcijām kā modalitātes izteicējām, kas lielā mērā ir debitīva semantiski analogi. Modāli verbi nekad nav uzskatīti par galvenajiem modalitātes izteicējiem, jo modāla (deontiska, retāk, epistēmiska) nozīme blakus verba izteiksmēm piemīt arī konstrukcijām bija/būs + nenoteiksme un ir/bija/būs + tagadnes pasīvais divdabis, kur finītajā formā ir verbs būt, kam leksiski nekādas modālas nozīmes nav.

\section{Polaritāte}

Lai skaidrāk izprastu verba nullformas morfosintaktisko būtību un lai pamatotu, kāpēc nebūtu vēlams runāt ne par modāla verba, ne bija/būs nullformu, svarīga ir arī polaritātes pārbaude - sastatot izteikumus apgalvojumā un noliegumā, iespējams pārliecināties, vai saglabājas viena un tā pati informācija.

Nolieguma formants latviešu valodā ir darbības vārda finītās formas priedēklis, kas pievienojas vai nu sintētiskai darbības vārda formai ((12a) piemērs), vai arī palīgverbam ((12b) piemērs) (Valkovska, Lokmane 2013, 789; sk. arī Ivulāne 2015), veidojot t. s. simetrisko noliegumu (par nolieguma tipoloǵiju plašāk sk. Dahl 2011, sk. arī Kalnača 2014).

(12) a. Es lasu grāmatu - Es nelasu grāmatu.

b. Es esmu lasījusi grāmatu - Es neesmu lasījusi grāmatu.

Tas pats simetriskā nolieguma princips darbojas arī tad, ja izteicējā ir konstrukcija modāls verbs + nenoteiksme:

(13) a. subjekts nominatīvā

Es varu lasìt grāmatu - Es nevaru lasìt grāmatu.

b. subjekts datīvā

Man vajag lasīt grāmatu - Man nevajag lasīt grāmatu.

Ja apgalvojuma teikumā ir palīgverba vai saitiņas nullforma, tad tā paša satura nolieguma teikumā parasti būs noliegts palīgverbs (14a) vai saitiņa (14b):

(14) a. Modinātājs o (ir) nozvanījis laikāa-Modinātājs nav nozvanījis laikā.

b. Diena (ir) loti skaista - Diena nav ļoti skaista. 


\subsection{Elipse}

Polaritātes un palīgverba/saitiņas/modāla verba nullformas sakarā svarīga ir arī elipses ${ }^{2}$ teorija - ja teikumā ir iespējams kāda elementa atmetums, tad jābūt kādai sintaktiskai struktūrai, kas norāda uz atmesto elementu (Aelbrecht 2008; Gergel 2009; sk. arī Crystal 1997, 134; Matthews 1997, 111). Respektējot iepriekš minēto simetriskā nolieguma principu latviešu valodā, sintaktiska struktūra, kas atspoguļo kādu atmestu (t. i., nullformā esošu) izteicēja daļu, ir noliegums, sk. (14) piemēru.

Ja tiek uzskatīts, ka teikumā iespējama modāla verba nullforma, tad simetriskā nolieguma principam vajadzētu darboties arī šajā gadījumā - apgalvojumā elidējot modālu verbu, noliegumā tam jāparādās ar priedēkli ne-, saglabājoties teikuma propozīcijai (sal., piem., (13a) un (13b) teikumus). Tātad (15a) piemērā minētajam apgalvojuma teikumam ar subjektu datīvā noliegumā būtu sagaidāma atbilstoša teikuma konstrukcija un kāds modāls verbs, piem., nevajag (15b):

(15) a. apgalvojums

Ko man tagad $\boldsymbol{o}$ darīt?

b. noliegums

Ko man tagad nevajag darīt?

Tomēr rodas šaubas, vai (15b) piemērā īstenojas simetrisks noliegums un vai noliegts modāls verbs atspoguḷo apgalvojumā (15a) šķietami elidēto verbu un teikums kopumā izsaka to pašu informāciju, ko (15a) minētais teikums. Nepārprotami redzams, ka nolieguma teikums Ko man tagad nevajag darīt? propozīcijas zin̄ā atspoguḷo apgalvojuma teikumu Ko man tagad vajag darît?, bet ne teikumu Ko man tagad darīt? Tas liek domāt, vai teikumos, kur izteicējs ir nenoteiksme, vispār var runāt par kādu modāla verba nullformu. Šķiet, ka ne, turklāt šādi gadījumi nebūs saistāmi ar elipsi.

\subsection{Izteicējs - nenoteiksme noliegumā}

Par labu tam, ka nenoteiksme ir īpašs izteicēja paveids un nepārstāv konstrukciju ar elidētu modālu verbu, liecina piemēri, kur izteicējā ir nenoteiksme noliegumā, t. i., nolieguma priedēklis ne- pievienojies tieši pie pilnnozīmes verba. Šādam izteicējam iespējamas dažādas deontiskās modalitātes nozīmes (sk. arī Kalnača 2013b), piem.:

\section{1) varējums}

(16) Jums, veselajiem, to [slimošanu] nesaprast! (www.tvnet.lv)

'Jūs, veselie, to nevarat saprast!'

2 Latviešu valodniecībā šai izpratnē parasti lietots termins redukcija (sk., piem., termina 1. nozīmi Skujiņa 2007, 322). Tomēr redukcijas jēdziens vispārīgajā valodniecībā primāri tiek saistīts ar fonētikas jomu (sk., piem., Crystal 1997, 324 ), savukārt teikuma struktūras izlaidumu aprakstā tiek lietots termins elipse (sk., piem., Crystal 1997, 134; Matthews 1997, 111), kas izmantots arī šai rakstā. 


\section{2) iespējamība}

(17) Prezidentam neiztikt bez inteliǵences, izglìtības un mugurkaula. (www.tvnet.lv) 'Prezidentam nav iespējams iztikt bez inteliǵences .. / Prezidents nevar iztikt ..'

\section{3) aizliegums}

(18) Virsdrēbēs neienākt!

'Virsdrēbēs nedrīkst/aizliegts ienākt!'

\section{4) nosacijjums}

(19) Kā nepadarīt sevi vecāku? (Ieva)

'Kā lai nepadara sevi vecāku?'

Kā redzams piemēros (16)-(19), modālas nianses variējas atkarībā no konkrētas situācijas un izsakāmā satura. Tas liek apšaubīt kāda konkrēta modāla verba esamību apgalvojumā un norāda uz to, ka nenoteiksme ir īpašs izteicēja tips.

\subsection{Simetriskas polaritātes trūkums}

Nenoteiksme noliegta verbāla izteicēja funkcijā rada grūtības tai ziṇā, ka vērojams arī simetriskas polaritātes trūkums - ne visos gadījumos iespējami atbilstoši apgalvojuma teikumi. Tā (16) un (17) piemēram apgalvojuma teikums nav iespējams ar verbu bez priedēkḷa ne-:

(20) a. *Jums, veselajiem, to [slimošanu] saprast!

b. *Prezidentam iztikt bez inteligences, izglìtības un mugurkaula.

Abos gadījumos apgalvojumā var būt dažādas sintaktiskas konstrukcijas, piem., vai nu ar modālu verbu varēt un subjektu nominatīvā (piemēri (21a-b)), vai arī ar konstrukciju ir + tagadnes pasīvais divdabis un subjektu datīvā ((22) piemērs):

(21) a. Jüs, veselie, to varat saprast!

b. Prezidents var iztikt bez inteligences, izglìtības un mugurkaula.

(22) Prezidentam ir iespējams iztikt bez inteligences, izglītības un mugurkaula.

Iespējama arī vajadzības izteiksme:

(23) a. Jums, veselajiem, tas jāsaprot!

b. Prezidentam jäiztiek bez inteligences, izglìtības un mugurkaula.

No vienas puses, šāds simetriskas polaritātes trūkums varētu liecināt, ka tomēr būtu vērts apsvērt ideju par modāla verba nullformu blakus nenoteiksmei. Taču, no otras puses, semantiski atbilstošie apgalvojuma teikumi ir dažādas no noliegtajiem teikumiem atšķirīgas sintaktiskas konstrukcijas, t. sk. vajadzības izteiksme. Tas savukārt liek tomēr noraidīt ideju par modāla verba nullformu - jo atškiirīgas konstrukcijas teikumi apgalvojumā un noliegumā nav saistāmi ar vienu un to pašu informāciju. Tie tādā gadījumā ir divi atšķirīgi teikumi, turklāt katram ir sava propozīcija. 


\section{Secinājumi}

Latviešu valodā nevar uzskatīt, ka nenoteiksme izteicējā īstenojas tikai kopā ar reālu vai potenciālu modālu verbu, t. i., nevar runāt par modāla verba nullformu.

Modalitāte nav saistāma tikai ar modāliem verbiem - modalitāti izsaka gan verba izteiksmes, gan dažādas sintaktiskas konstrukcijas.

Nenoteiksme kā vienkāršs verbāls izteicējs latviešu valodā pārstāv lai gan marginālu, bet tomēr īpašu sintaktisku konstrukciju. Tai blakus nav postulējama ne modāla verba, ne ir nullforma.

Teikumi ar nenoteiksmi un konstrukcijām bija/būs ir ierobežoti komunikatīvo tipu un laika/izteiksmju lietojuma ziṇā, tiem ir arī dažādas polaritātes attieksmes apgalvojumā un noliegumā. Tas neļauj teikumos ar nenoteiksmi izteicējā rekonstruēt kādus noteiktus un regulārus modālus verbus.

Turpmāk būtu pētāma nenoteiksmes un konstrukciju bija/būs + nenoteiksme polaritāte un teikuma komunikatīvie tipi, kā arī to iespējamais paralēlisms ar modāliem verbiem un verba izteiksmēm apgalvojumā un noliegumā.

\section{Avoti}

1. Ābele, Inga. 2014. Klūgu mūks. Rīga: Dienas Grāmata.

2. Diena (laikraksts)

3. Ieva (žurnāls)

4. Ikstena, Nora. 2011. Vìrs zilajā lietusmētelìtīi. Rīga: Dienas Grāmata.

5. Joņevs, Jānis. 2014. Jelgava 1994. Rīga: Mansards.

6. www.apollo.lv

7. www.delfi.lv

8. www.lsm.lv

9. www.tvnet.lv

\section{Literatūra}

1. Aelbrecht, Lobke. 2008. Dutch modal complement ellipsis. Empirical Issues in Syntax and Semantics. 7. Bonami, Olivier \& Patricia Cabredo Hofherr (eds.), 7-33.

2. Ahero, Antonija et al. 1959. Mūsdienu latviešu literārās valodas gramatika. I. Fonētika un morfolog̣ija. Rīga: Latvijas PSR Zinātnu akadēmijas izdevniecība.

3. Ambrazas, Vytautas (red.). 1996. Dabartinès lietuviu kalbos gramatika. Vilnius: Mokslo ir enciklopedijų leidykla.

4. Crystal, David. 1997. A Dictionary of Linguistics and Phonetics. Blackwell Publishers.

5. Dahl, Östen. 2011. Typology of negation. The Expression of Negation. Horn, Laurence R. (ed.). De Gruyter Mouton, 9-38.

6. Gergel, Remus. 2009. Modality and Ellipsis. Diachronic and Synchronic Evidence. Berlin/New York: Mouton de Gruyter.

7. Ivulāne, Baiba. 2015. Palı̄gnozīmē lietotu darbības vārdu sistēma latviešu valodā. Promocijas darbs filolog̣ijas doktora grāda iegūšanai. Rīga: LU. 
8. Kalnača, Andra. 2013a. Artura Ozola analītiskais debitīvs mūsdienu interpretācijā. Arturs Ozols (1912-1964). In Honorem. Res Latvienses II. Kalnača, Andra, Lāms, Ojārs (sast. un red.). Rīga: LU Akadēmiskais apgāds, 35-44.

9. Kalnača, Andra. 2013b. Darbības vārds (verbs). Latviešu valodas gramatika. Nītiņa, Daina, Grigorjevs, Juris (red.). Rīga: LU Latviešu valodas institūts, 456-564.

10. Kalnača, Andra. 2014. Nolieguma un modalitātes attieksmes. Valoda: nozīme un forma. 5. Kalnača, Andra, Lokmane, Ilze (sast. un red.). Rīga: LU Akadēmiskais apgāds, 72-79.

11. Lokmane, Ilze. 2013. Vienkārša teikuma formālā (strukturālā) organizācija. Latviešu valodas gramatika. Nīinna, Daina, Grigorjevs, Juris (red.). Rīga: LU Latviešu valodas institūts, $710-766$.

12. Lokmane, Ilze. 2014. Verbāls sastata izteicējs latviešu valodā. Valoda: nozīme un forma. 4. Kategoriju robežas gramatikā. Kalnača, Andra, Lokmane, Ilze (sast. un red.). Rīga: LU Akadēmiskais apgāds, 111-118.

13. Lokmane, Ilze. 2016. Darbības vārda sintaktiskās nullformas latviešu valodā. Valoda: nozīme un forma 7. Gramatika un saziņa. Kalnača, Andra, Lokmane, Ilze, Horiguchi, Daiki (sast. un red.). Rīga: LU Akadēmiskais apgāds, 116-126.

14. Matthews, Peter H. 1997. Concise Dictionary of Linguistics. Oxford: Oxford Universiy Press.

15. Ozols, Arturs. 1993. Latviešu tautasdziesmu valoda. Rīga: Zvaigzne. [Pirmizdev. Rīga: Latvijas Valsts izdevniecība, 1961].

16. Paulauskienè, Aldona. 1994. Lietuviu kalbos morfologija. Vilnius: Mokslo ir enciklopedijų leidykla.

17. Paulauskienè, Aldona. 2014. [Recenzija par:] Latviešu valodas gramatika. Acta Linguistica Lithuanica. LXXI. Vilnius: Lietuvių kalbos institutas, 364-391.

18. Valkovska, Baiba, Lokmane, Ilze. 2013. Teikuma komunikatīvā struktūra. Latviešu valodas gramatika. Nītiņa, Daina, Grigorjevs, Juris (red.). Rīga: LU Latviešu valodas institūts.

\section{Summary}

Infinitive as a verbal predicate is one of the means of expressing modality in Latvian. Infinitive expresses deontic or, rarely, epistemic modality. Besides the infinitive, modality in Latvian is expressed by different moods, which play the main role. Different modal constructions with modal verbs (+ infinitive) and participles are also widely used. The present paper is devoted to the analysis of relations between the infinitive and modal constructions, and the modal meanings expressed by the infinitive and modal constructions. The crucial question of the analysis is - could any zero form of modal verb be possible in Latvian? It is connected with the interpretation of the (morpho)syntactic status of the infinitive in the function of predicate. If we agree that the infinitive is a simple verbal predicate then the answer is NO, and zero form of modal verb is impossible in Latvian. If, however, we think that the infinitive is a compound predicate then the answer is YES, because such predicate is similar to other nominal, verbal or adverbial compound predicates in Latvian, where zero forms (mainly in the $3^{\text {rd }}$ person, present) are widespread.

However, polarity tests do not approve the idea of zero forms of modal verbs in Latvian. 